\title{
Potential application of lactic acid starters in the reduction of aflatoxin contamination in fermented sorghum-millet beverages
}

Stellah Byakika ${ }^{1 *}$, Ivan Muzira Mukisa', Alex Paul Wacoo ${ }^{2,3,4}$, Remco Kort ${ }^{2,3}$, Yusuf Byenkya Byaruhanga ${ }^{1}$ and Charles Muyanja'

\begin{abstract}
Background: Aflatoxin contamination in traditionally fermented cereal-based beverages is a serious food safety challenge considering that commercialization of these products is rising. The challenge is aggravated by the fact that aflatoxin elimination from the food chain is almost impossible. This paper focuses on Obushera, a popular traditional spontaneously fermented sorghum - millet beverage from Uganda.

Method: Mold and total aflatoxin levels in cereal flours and Obushera from different markets in Kampala were determined. Ability of lactic acid bacteria (LAB) starters from Obushera; Lb. plantarum MNC 21, W. confusa MNC 20 and L. lactis MNC 24 to bind aflatoxin B1 (AFB1) was evaluated against Lb. rhamnosus yoba 2012 as the reference strain.

Results: Mold counts in sorghum, millet and Obushera ranged between 0.0-2.4 log cfu/g, 2.0-6.5 log cfu/g and 2.0-5.5 $\log \mathrm{cfu} / \mathrm{g}$, respectively. None of the flours complied with food safety standards for molds (maximum $=4 \mathrm{log} \mathrm{cfu} / \mathrm{g}$ ) while 88.0\% of Obushera did (standard = maximum $1.3 \mathrm{log}$ cfu/g). Total aflatoxin levels in sorghum, millet and Obushera were $22.3 \pm 21.2 \mathrm{ppb}, 9.9 \pm 10.0 \mathrm{ppb}$ and $10.4 \pm 6.1 \mathrm{ppb}$, respectively. LAB bound 19.3-69.4\% of AFB1 in a $1000 \mathrm{ppb}$ solution with binding efficiency in the order of $L b$. rhamnosus yoba $2012=L b$. plantarum MNC $21>W$. confusa MNC $20=$ L. lactis MNC 24. The LAB-AFB1 complex remained stable under a series of washes with physiological saline.

Conclusion: This study indicates that $L A B$ with aflatoxin binding properties can be exploited for controlled cereal fermentations to improve food safety.
\end{abstract}

Keywords: Aflatoxin, Fermentation, Lactic acid bacteria, Sorghum, Millet, Food safety

\section{Introduction}

Aflatoxins are toxic, carcinogenic and immunosuppressive metabolites of various strains of Aspergillus (A.), mainly $A$. flavus, A. parasiticus, A. nomius and A. tamarii (Udovicki et al. 2018a; Iyanda et al. 2014; Black et al. 2013). The major aflatoxins are B1 (AFB1) - the most lethal, B2 (AFB2), G1 (AFG1) and G2 (AFG2) (Romani 2004). Aflatoxin contamination outbreaks cause fatalities. An outbreak in India caused 106 fatalities in 1974 (Reddy and Raghavender 2007). Another in Kenya led to 317 cases

\footnotetext{
* Correspondence: stellahbyakika@gmail.com

'Department of Food Technology and Nutrition, School of Food Technology Nutrition and Bioengineering, College of Agricultural and Environmental Sciences, Makerere University, P.O. Box 7062, Kampala, Uganda Full list of author information is available at the end of the article
}

and 125 deaths in 2014 (Probst et al. 2007). In Tanzania, it led to 68 cases and 20 deaths in 2016 (Kamala et al. 2018). The outbreaks were linked to consumption of aflatoxin contaminated maize.

Cereal-based fermented beverages such as beers and non-alcoholic lactic acid bacteria (LAB) fermented beverages are popular around the world. Although the non-alcoholic fermented beverages are more common in rural areas, particularly in low-income countries, commercialization has resulted in a renewed interest among urban populations. The beverages are popular for their social, religious, nutritional and therapeutic benefits (Aka et al. 2008).

Cereal-based fermented beverages are mainly made from maize, sorghum, millet and barley (Aka et al. 2014; 
Osamwonyi and Wakil 2012). The cereals often contain aflatoxins which end up in the beverages (Ezekiel et al. 2018; Garrido et al. 2012; Warth et al. 2012). Indeed, aflatoxin contamination in traditional beverages is reported (Ezekiel et al. 2018; Odhav and Naicker 2002). There are also reports on aflatoxins in industrial fermented cereal-based beverages (Mably et al. 2005; Nakajima et al. 1999; Nigussie et al. 2018; Peters et al. 2017; Scott and Lawrence 1997). It is likely that there are high occurrences of aflatoxins in traditionally fermented cereal-based beverages since controls are not as strict as in industrial processes.

Prevention of aflatoxin contamination, their detoxification or removal from food is crucial for consumer safety. However, complete removal from food is nearly impossible. Even cooking does not eliminate them so other methods are proposed (Kumar et al. 2017; El-Nezami et al. 1998). Physical methods entail cleaning, irradiation and adsorption while chemical methods use ozone and other chemicals (Jalili 2016). Unfortunately, many of these methods are costly, impractical, toxic, contradict FAO requirements, destroy nutrients and alter sensory properties (Verheecke et al. 2016; Huwig et al. 2001). So, biological methods where microbes degrade, bind or inhibit aflatoxins synthesis are better (Jalili 2016). Degradation is irreversible but binding may be reversible for some strains (Verheecke et al. 2016; Hernandez-Mendoza et al. 2009).

Conflicting results of LAB-AFB1 binding exist (Shetty and Jespersen 2006; Taheur et al. 2017; Westby et al. 1997). Discrepancies relate to the strain specificity of this property, highlighting the need to examine different strains (Peltonen et al. 2001). Lactobacillus (Lb.) plantarum MNC 21, Lactococcus (L.) lactis MNC 24 and Weisella (W.) confusa MNC 20 are excellent starters for Obushera (Mukisa et al. 2012; Mukisa et al. 2017) but their AFB1 binding abilities were unknown. Considering that there is increasing global interest in probiotics, LAB with AFB1 binding and starter culture abilities would be vital in improving food processing, food safety and consumer health (Shetty and Jespersen 2006). Therefore, this study determined aflatoxin levels in sorghum and millet flours and Obushera sold in Kampala. Obushera is a name for popular traditional fermented or non-fermented sorghum and/or millet beverages from Uganda (Mukisa et al. 2012). Furthermore, the AFB1 binding abilities of the Obushera starters were evaluated. Lb. rhamnosus GG a known probiotic was the positive control (Kankaanpää et al. 2000).

\section{Materials and methods Materials \\ Cereal flours and Obushera}

Flours of sorghum $(n=20)$ and millet $(n=20)$ were purchased from common wholesale points in Kampala where majority of the processors obtain their raw materials for Obushera processing. The most commonly sold type of Obushera known as Obutoko $(n=59)$ was purchased from different processors in Kampala. Obutoko is majorly made from sorghum but millet may be added as a source of indigenous starter cultures. Samples were transported in cool boxes containing ice blocks to the laboratory for analysis.

\section{Microbial strains}

Lb. plantarum MNC 21, L. lactis MNC 24 and W. confusa MNC 20 strains previously isolated from Obushera were used (Mukisa et al. 2012). Lb. rhamnosus yoba 2012 (originally named $L b$. rhamnosus GG) was obtained from Yoba for Life Foundation Amsterdam, The Netherlands. The strains were separately pre cultured in MRS broth (Laboratorios CONDA, Madrid, Spain) at $30^{\circ} \mathrm{C}$ for $24 \mathrm{~h}$. Lb. rhamnosus yoba 2012 was pre-cultured in MRS broth with tween 80 at $37^{\circ} \mathrm{C}$ in an atmosphere containing $5 \%$ $\mathrm{CO}_{2}$ for $24 \mathrm{~h}$. After incubation, cell pellets were centrifuged at $3200 \mathrm{x} \mathrm{g}$, for $10 \mathrm{~min}$ at $25^{\circ} \mathrm{C}$. The pellets were then washed twice using physiological saline and subsequently serially diluted to obtain a cell concentration corresponding to $7 \log \mathrm{cfu} / \mathrm{ml}$.

\section{Analyses \\ Enumeration and identification of molds}

Mold counts were determined by surface spreading selected serial dilutions on pre-poured Potato Dextrose Agar (PDA) (Laboratorios CONDA, Madrid, Spain) containing $1 \%$ lactic acid. The plates were incubated at $25^{\circ} \mathrm{C}$ for 7 days. For identification, mold colonies were picked from high dilution plates and sub-cultured on pre poured acidified PDA plates to obtain pure colonies. Mold identification was based on visual and microscopic examination according to Jay (1992). The morphological characteristics of the molds were also examined using a microscope (020-518.500 DM/LS I/98, Leica, Germany).

\section{Determination of total aflatoxin content in cereal flours and Obushera}

Total aflatoxin content was determined using the RIDASCREEN $^{\circ}$ total aflatoxin enzyme immunoassay (R-Biopharm AG, Darmstadt, Germany). Briefly, $2 \mathrm{~g}$ of flour or $2 \mathrm{~mL}$ of Obushera $(\mathrm{pH}=6)$, neutralized with 1 $\mathrm{M} \mathrm{NaOH}$ were separately added into screw cap glass vials. Ten milliliters of methanol/distilled water $(70 / 30$; $v / \mathrm{v}$ ) were mixed with the flour or beverage for $10 \mathrm{~min}$ at $25^{\circ} \mathrm{C}$. The extract was filtered (pore size: $11 \mu \mathrm{m}$, Whatman No. 1, Whatman GE Healthcare) and $100 \mu \mathrm{L}$ of filtrate diluted with $600 \mu \mathrm{l}$ of distilled water. Then $50 \mu \mathrm{l}$ of standard solution or prepared sample were pipetted into duplicate wells followed by $50 \mu$ l of peroxidase conjugated aflatoxin $\mathrm{B} 1$ and $50 \mu \mathrm{L}$ of antibody solution. The 
preparations were manually mixed, and incubated in the dark at $25^{\circ} \mathrm{C}$ for $30 \mathrm{~min}$. The wells were emptied and rinsed thrice with washing buffer. A hundred microliters of substrate/chromogen were added to the wells, mixed and incubated in the dark at $25^{\circ} \mathrm{C}$ for $15 \mathrm{~min}$. A hundred microliters of stop solution were then added to the wells, mixed and absorbance read at $450 \mathrm{~nm}$ within 30 min of adding stop solution.

\section{Evaluation of AFB1 binding by lactic acid bacteria}

The ability of the lactic acid bacteria to bind AFB1 was determined according to the method described by Wacoo et al. (2019).

\section{Statistical analyses}

Data for AFB1 binding efficiency was analyzed using analysis of variance to test for significance differences at an $\alpha$ value of $5 \%$. The Tukey's HSD test was used to separate the means. Analyses were performed by XLSTAT software (version 2010.5.02, Addinsoft, France). Data on mold incidence was analyzed using descriptive statistics and results presented as frequencies and means with standard deviations.

\section{Results and discussion}

Mold incidence and total aflatoxin levels in Obushera and cereal flours

\section{Mold incidence in Obushera and cereal flours}

Table 1 summarizes the concentration of molds in Obushera and cereal flours and their conformance to food safety standards. Figure 1 shows the incidence of molds in the flours and Obushera. Sorghum flours were the most contaminated with more than half of the samples testing positive for A. flavus, A. niger, Penicillium spp and Fusarium spp. The same types of molds were found in Obushera, although their incidence was generally less than in the flours. The most prominent mold in the beverage was A. niger. Majority (88.0\%) of Obushera samples complied with the standards for mold levels while all the cereal flours did not comply with the respective specifications.

Table 1 Mold contamination levels in cereal flours and Obushera and conformance to food safety standards

\begin{tabular}{lllll}
\hline Food matrix & Molds & \multicolumn{3}{l}{ Conformance to food safety standards } \\
\cline { 3 - 6 } & (log cfu/g) & $\begin{array}{l}\text { Max. } \\
\text { (log cfu/g) }\end{array}$ & $\begin{array}{l}\text { \% Conforming } \\
\text { samples }\end{array}$ & Standard \\
\hline Sorghum flour & $5.1 \pm 1.4$ & 4 & 0.0 & EAC (2016) \\
Millet flour & $3.6 \pm 1.4$ & 4 & 0.0 & EAC (2011) \\
Obushera & $1.4 \pm 0.7$ & 1.3 & 88.0 & UNBS (2009)
\end{tabular}

Values are means \pm standard deviations. Obushera $(n=59)$, Sorghum flour $(n=$ 20), Millet flour $(n=20)$
Limited data exist on the diversity and levels of fungal contamination in fermented cereal beverages, sorghum and millet flours. None-the-less our results agree with the available data. Similar to other studies, A. flavus, A. niger, Penicillium spp., and Fusarium spp. were reported as the common fungal contaminants in sorghum and millet flours (Hussaini et al. 2009; Osamwonyi and Wakil 2012; Weledesemayat et al. 2016). The levels of mold contamination in this study are also in agreement with other authors (N'Guessan et al. 2014; Alborch et al. 2012; Plavšić et al. 2017; Ntuli et al. 2013). Cereal grains such as maize, sorghum and millet, which are common raw materials for traditional fermented beverages, are quite susceptible to molds contamination (Ezekiel et al. 2018). Mold contamination in cereals is linked to pre and postharvest contamination of grains. Insect damage, drought stress, inadequate drying and poor storage practices facilitate mold proliferation in grains and subsequently in the flours (Hell et al. 2000). Moldy grain may be milled and used to make flours for food and fermented or non-fermented beverages. Furthermore, residual flour in the mills may contaminate subsequent batches (Berghofer et al. 2003; Ntuli et al. 2013). This study therefore, further illustrates that cereal flours are sources of aflatoxin contamination in fermented and unfermented beverages.

The presence of molds in Obushera and related fermented cereal products has been reported before. Kateu (1998) observed contamination of Obushera with Aspergillus spp., Penicillium spp., Mucor spp. and Rhizopus spp. The total mold counts observed in this study were in the range (2-8 log cfu/g) reported by Kateu (1998). In a similar study, Mashak et al. (2014) also reported 3.5 $\log \mathrm{cfu} / \mathrm{g}$ of molds in Kashk-e Zard, an Iranian wheat-based fermented beverage. However, their study did not mention the mold genera. In contrast, Odhav and Naicker (2002) did not find molds in traditionally brewed South African beers: Imfulamfula, Umqombothi and Isiqatha. The presence of various mold types in food is a safety concern, however, the occurrence of A. flavus in raw materials and Obushera is particularly alarming given its aflatoxigenic potential. Therefore, the use of aflatoxin free or minimally contaminated raw materials is important for production of safe cereal-based beverages.

\section{Aflatoxin contamination in Obushera and cereal flours}

Table 2 summarizes the total aflatoxin levels in the sorghum flours, millets flours and Obushera. The table also shows the proportions of Obushera and cereal flours that complied with the food safety standards for total aflatoxins. Mean total aflatoxin concentrations ranged from $9.9 \mathrm{ppb}$ in millet flour to $22.3 \mathrm{ppb}$ in sorghum flour. About $50-75 \%$ of the samples of flours and Obushera conformed to the specifications for aflatoxin contamination. 


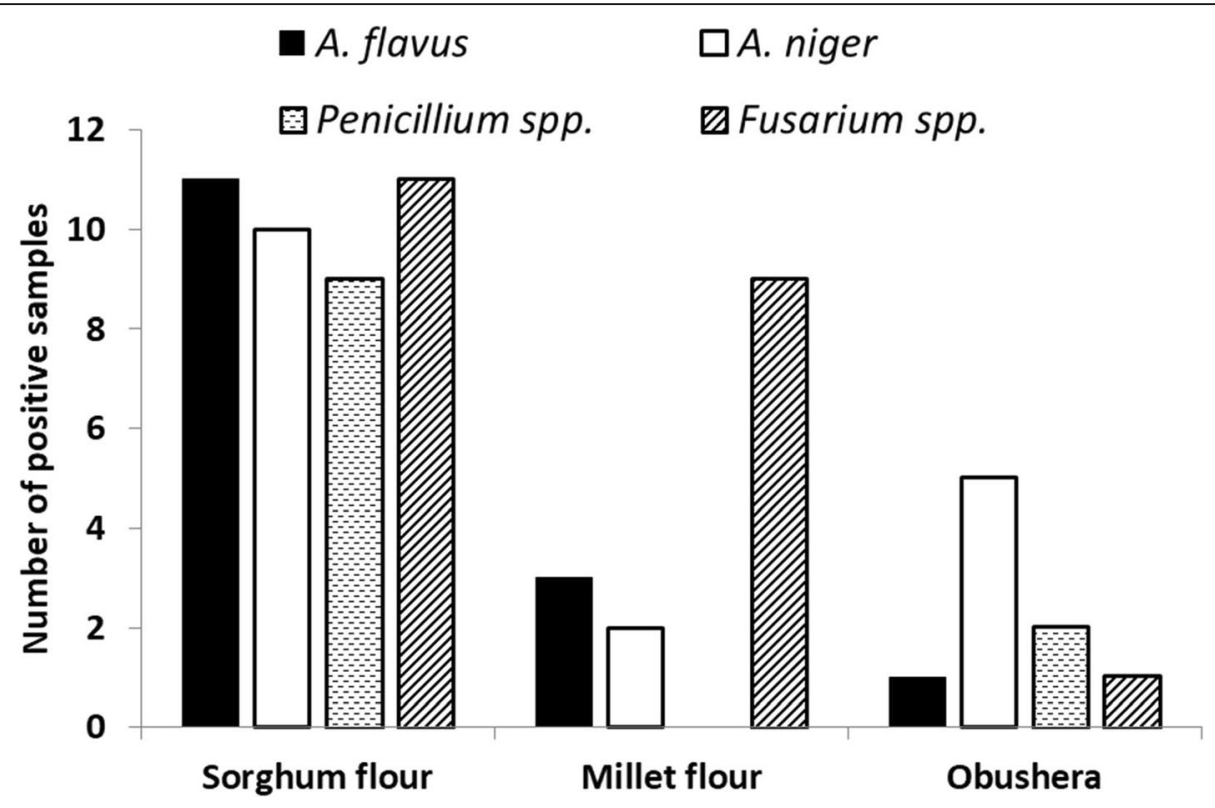

Fig. 1 Incidence of molds in sorghum, millet and Obushera. Obushera $(n=59)$, Sorghum flour $(n=20)$, Millet flour $(n=20)$

Generally, more samples of Obushera than cereal flours conformed to the specifications for total aflatoxins.

Similar findings have been reported with respect to aflatoxin contamination in cereal flours and cereal-based beverages. Kihara (2015) reported $<1-80.5 \mathrm{ppb}$ of total aflatoxins in sorghum flours and 1.0-248.8 ppb in millet flours sampled from Nairobi, Kenya. Furthermore, up to $1000 \mathrm{ppb}$ and $2110 \mathrm{ppb}$ aflatoxins have been reported in laboratory pulverized sorghum and millet grains, respectively (Odoemelam and Osu 2009; Sirma et al. 2016; Weledesemayat et al. 2016). Bationo et al. (2015) detected up to $255 \mathrm{ppb}$ aflatoxins in sorghum malt from Ouagadougou, Burkina Faso. In contrast, Makun et al. (2014) reported no aflatoxin contamination in millet grains from Nigeria. Despite A. flavus infection, Odhav

Table 2 Aflatoxin levels in cereal flours and Obushera and conformance to food safety standards

\begin{tabular}{|c|c|c|c|c|}
\hline \multirow[t]{2}{*}{ Food matrix } & \multirow{2}{*}{$\begin{array}{l}\text { Total } \\
\text { aflatoxins } \\
\text { (ppb) }\end{array}$} & \multicolumn{3}{|c|}{ Conformance to food safety standards } \\
\hline & & Max. (ppb) & $\begin{array}{l}\text { \% Conforming } \\
\text { samples }\end{array}$ & Standard \\
\hline \multirow[t]{2}{*}{ Sorghum flour } & $22.3 \pm 21.2$ & 4 & 50.0 & EU (2006) \\
\hline & & 10 & 60.0 & EAC (2016) \\
\hline \multirow[t]{2}{*}{ Millet flour } & $9.9 \pm 10.0$ & 4 & 60.0 & EU (2006) \\
\hline & & 10 & 75.0 & EAC (2011) \\
\hline \multirow[t]{2}{*}{ Obushera } & $10.4 \pm 6.1$ & 4 & 66.0 & EU (2006) \\
\hline & & 10 & 88.0 & UNBS (2009) \\
\hline
\end{tabular}

Values are means \pm standard deviations. Obushera $(n=59)$, Sorghum flour $(n=$ 20), Millet flour $(n=20)$, ND - not detected (detection limit; $1.75 \mathrm{ppb})$. Number of samples ND for Obushera, sorghum flour and millet flour is 33,9 and 10 , respectively and Naicker (2002) detected no aflatoxins in sorghum grain from South Africa. It is important to note that the conditions favorable for fungal growth in grains are not always conducive for mycotoxin production (Mannaa and Kim 2017). Mycotoxin production is dependent on the microbial strain, substrate type, temperature and water activity $\left(\mathrm{a}_{\mathrm{w}}\right)$ and climatic seasons (Abdel-Hadi et al. 2012; Klich 2007; Mousa et al. 2013; Obonyo and Salano 2018; Udovicki et al. 2018b). For instance, Abdel-Hadi et al. (2012) reported that optimal growth of A. flavus occurs at $30-35{ }^{\circ} \mathrm{C}$ and $0.99 \mathrm{a}_{\mathrm{w}}$, whereas the optimum conditions for aflatoxin production are $25-30^{\circ}$ $\mathrm{C}$ at $0.99 \mathrm{a}_{\mathrm{w}}$ and $30-35^{\circ} \mathrm{C}$ at $0.95 \mathrm{a}_{\mathrm{w}}$.

Other fermented cereal beverages have also been reported to contain aflatoxins. Odhav and Naicker (2002) reported aflatoxin contamination in traditionally brewed South African beers: Isiqatha (12 ppb) and Utshwala special (200 and $400 \mathrm{ppb}$ ). Matumba et al. (2014) also found about $90 \mathrm{ppb}$ of aflatoxin in traditional maize-based opaque beers from Malawi. Furthermore, traditional sorghum beers from Malawi contained up to $22 \mathrm{ppb}$ aflatoxin (Matumba et al. 2011). Okaru et al. (2017) reported aflatoxin contamination (3.5-6.8 ppb) in opaque sorghum and millet beers in Kenya. Surprisingly, Bationo et al. (2015) did not find AFB1 in sorghum beers which were made from AFB1 contaminated malt in Ouagadougou, Burkina Faso. Additionally, aflatoxins were also not detected in traditional sorghum beers in Botswana (Nkwe et al. 2005).

The contamination level of aflatoxins in fermented beverages is dependent on the initial concentration in the raw flours and the type of microbes involved in the 
fermentation. As shown in Table 2, the aflatoxin levels in Obushera were significantly lower than in the raw materials. Bationo et al. (2015), Ezekiel et al. (2015) and Nkwe et al. (2005) reported similar findings. Mycotoxin levels in fermented foods tend to be lower than in their raw materials because fermentation reduces their levels (Ezekiel et al. 2015; Karlovsky et al. 2016; Lee and Ryu 2017; Okeke et al. 2015). For instance, Matumba et al. (2011) observed that aflatoxin levels in thobwa, a cereal-based fermented beverage from Malawi, drastically reduced during fermentation. In another study, mycotoxin reductions of $76 \%$ in kunu-zaki and $59 \%$ in pito, both Nigerian cereal-based beverages were observed after fermentation (Ezekiel et al. 2015). Indeed, there are more studies that support the role of fermentation in reducing aflatoxin levels in fermented cereal-based beverages (Bationo et al. 2015; Chelule et al. 2010). Therefore, in the present study, fermentation could possibly explain the lower levels of total aflatoxins in Obushera in comparison to the flours (Table 2). The aflatoxin reduction could be attributed to the ability of certain LAB strains to bind, degrade or inhibit aflatoxin biosynthesis in food matrices (Mokoena et al. 2005; Nyamete et al. 2016).

Table 2 shows that some of the Obushera contained aflatoxins despite the evidence of fermentation. Although fermentation is reported to lower aflatoxin levels (Mokoena et al. 2005; Nyamete et al. 2016), the process is not always effective. In fact, some authors also reported the presence of aflatoxins in fermented products (Matumba et al. 2011; Matumba et al. 2014; Odhav and Naicker 2002). This could be attributed to the spontaneous nature of the fermentations. There is no guarantee that the wild cultures in the gruels can reduce aflatoxin levels. This therefore, necessitates identifying and using starter cultures with proven ability to effectively lower aflatoxin concentrations. Such cultures should be purified, propagated and commercialized for production of safe traditional fermented cereal-based beverages. Otherwise, habitual consumers of these products are potentially highly exposed to aflatoxins.

This study was mainly focused on evaluating the aflatoxin concentration in cereal flours and Obushera. However, the presence of Aspergillus, Fusarium and Penicillium species in the flours and Obushera is an indication that other mycotoxins such as ochratoxin A and trichothecenes (Udovicki et al. 2018a, 2018b) could be potential contaminants in this product and related beverages.

\section{Effect of Obushera LAB starters on aflatoxin B1 concentration in saline solution}

The percentage binding of AFB1 by the Obushera LAB starters in physiological saline is summarized in Fig. 2. The extents of binding by Lb. rhamnosus yoba 2012 and
Lb. plantarum MNC 21 were similar $(p>0.05)$ but higher $(p<0.05)$ than that of $W$. confusa MNC 20 and $L$. lactis MNC 24. Both W. confusa MNC 20 and L. lactis MNC 24 had similar binding capacities $(p>0.05)$. Three aqueous washes using physiological saline did not release the bound aflatoxin.

The use of LAB in binding of aflatoxins is considered a viable and safe strategy for lowering absorption and facilitating elimination of the toxins from the body (Hamidi et al. 2013). According to Peltonen et al. (2001), some LAB strains can bind aflatoxins to their cell walls or cell wall components thus lowering the bioavailability of the toxins.

Similar to other studies (Haskard et al. 2001; Peltonen et al. 2001), our work demonstrated the ability of LAB strains to bind AFB1 in spiked culture media. However, the results contradict findings of Taheur et al. (2017) who did not observe AFB1 binding by Lb. kefir KFLM3. This was possibly because aflatoxin binding is strain-dependent. In fact, there were notable differences in the AFB1 binding capabilities of our LAB strains (Fig. 2). Peltonen et al. (2001) noted the same for dairy strains of LAB and Bifidobacteria. These differences are possibly due to variations in the cell walls and cell-envelop structures of different strains. In spite of the differences, the three strains showed incredible ability (19-66\%) to bind $1000 \mathrm{ppb}$ of AFB1 (Fig. 2). Of the three strains, L. plantarum MNC 21 showed the highest $(p<0.05)$ binding ability. In fact, like the reference strain, it bound about three times more AFB1 than L. lactis MNC 24 and W. confusa MNC 20 (Fig. 2). Currently, literature states $400 \mathrm{ppb}$ as the highest aflatoxin level reported in a fermented cereal-based beverage (Odhav and Naicker 2002). Therefore, the ability of our LAB to bind close to $66 \%$ of $1000 \mathrm{ppb}$ AFB1 $(660 \mathrm{ppb})$ suggests their potential application in cereal fermentations with the aim of reducing the aflatoxin threat.

The usefulness of LAB in binding aflatoxins is subject to whether the binding is reversible or not or how stable the complex is to conditions of the gastrointestinal tract. Several researchers have reported reversible binding of AFB1 by LAB. Repeated aqueous washes released 62 and 50\% AFB1 bound by Lb. rhamnosus LC-705 and Lb. rhamnosus GG, respectively (Peltonen et al. 2001); Haskard et al. 2001). Reversible binding could be due to weak non covalent interactions between the toxin and the microorganism (Taheur et al. 2017; Peltonen et al. 2001). Fortunately, unbinding appears to be strain dependent and even when it occurs, not all the toxin is unbound. For instance, Haskard et al. (2001) observed 38 and 50\% AFB1 retention by $L b$. rhamnosus LC-705 and Lb. rhamnosus GG, respectively following several washes. It is also important to 


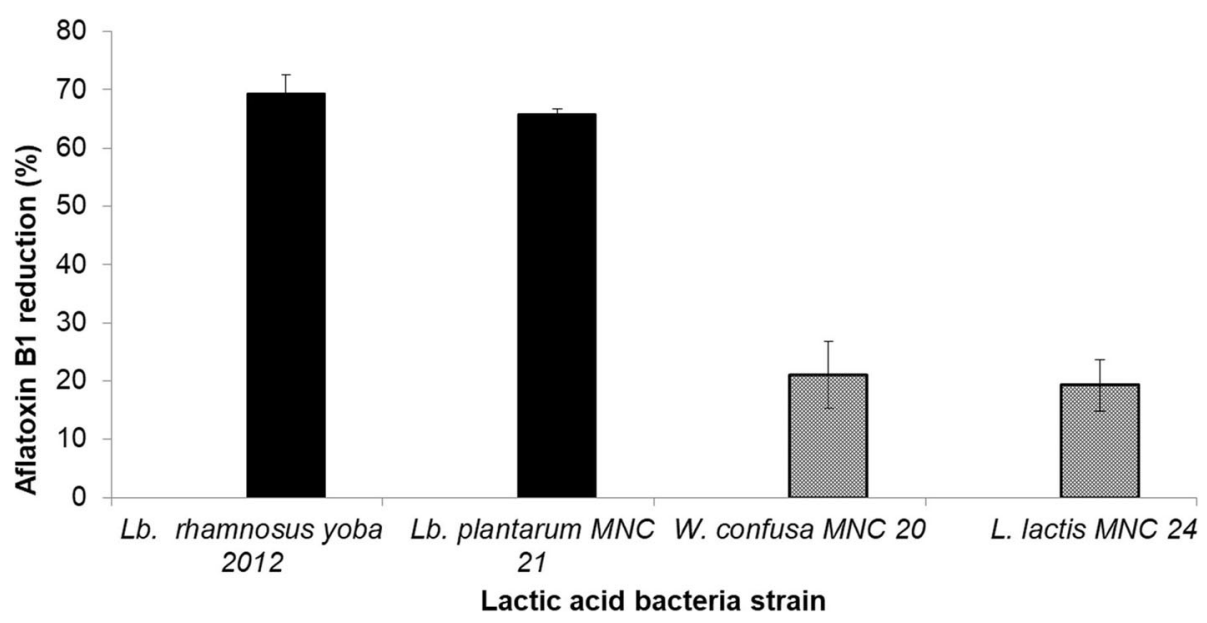

Fig. 2 Reduction of aflatoxin B1 content by Obushera lactic acid bacteria starters in saline solution. Values are means of three independent determinations. Error bars represent standard deviations. Percentage reduction is based on an initial concentration of $1.0 \mu \mathrm{g} / \mathrm{ml}$ AFB1

note that there are studies that have reported excellent stability of the AFB1-LAB complex especially for heat and acid treated cells. Utami et al. (2017) noted only 0.3 and $0.4 \%$ release of AFB1 by acid treated $L b$. acidophilus LC 1 and Lb. acidophilus ATCC 4356, respectively after five washes using phosphate buffer saline. Although our study suggested stable in vitro binding, the findings cannot at this point guarantee the stability of the AFB1-LAB complexes under gastrointestinal conditions. We can only speculate, at the moment that the complexes formed between our LAB and AFB1 are stable under gastrointestinal conditions and may aid the excretion of AFB1 from the body as has been reported for different LAB strains (El-Nezami et al. 2000; Gratz et al. 2004; Gratz et al. 2006; Huang et al. 2017; Kankaanpää et al. 2000; Liew et al. 2018).

\section{Conclusion}

The presence of aflatoxins in cereals and traditional fermented cereal beverages such as Obushera is of public health concern considering the adverse effects of these toxins. Therefore, an integrated approach should be considered to mitigate aflatoxin contamination in raw materials and in the subsequent products. Different actors in the value chains of cereals such as sorghum and millet that are used for producing fermented traditional products should be sensitized on appropriate practices for preventing aflatoxin contamination in grain. Processors of traditional fermented products should also ensure that they use cereal grains or flours that meet specifications for aflatoxin content. Furthermore, processors should also consider using starter cultures such as Lb. plantarum MNC 21, L. lactis MNC 24 and W. confusa MNC 20 to bind residual aflatoxins. Future studies should evaluate the potential of spontaneous fermentations, Obushera lactic starters and $L b$. rhamnosus yoba 2012 in reducing aflatoxin contamination in spiked samples. Additionally, the stability of the LAB-AFB1 complex should be evaluated under gastro intestinal conditions.

\section{Abbreviations \\ A.: Aspergillus; AF: Aflatoxin; aw: Water activity; cfu: colony forming units; L.: Lactococcus; LAB: Lactic acid bacteria; Lb.: Lactobacillus; PDA: Potato Dextrose Agar; ppb: parts per billion; W.: Weisella}

\section{Acknowledgements}

The authors thank Mr. Brighton Kansiime-Mukama and Mr. Daniel Muwanguzi for their assistance in sample collection. The authors are also grateful to the Obushera processors for their cooperation in the study.

Funding

Self-funded.

Availability of data and materials

All datasets from which conclusions of the manuscript have been drawn are presented in the paper.

Authors' contributions

SB collected data and wrote the manuscript, APW contributed to data collection particularly aflatoxin analyses, IMM planned the research, SB, APW, RM, IMM, YBB and CM reviewed the manuscript and approved it.

\section{Competing interests}

The authors declare that they have no competing interests.

\section{Publisher's Note}

Springer Nature remains neutral with regard to jurisdictional claims in published maps and institutional affiliations.

\section{Author details}

'Department of Food Technology and Nutrition, School of Food Technology Nutrition and Bioengineering, College of Agricultural and Environmental Sciences, Makerere University, P.O. Box 7062, Kampala, Uganda. ${ }^{2}$ Department of Molecular Cell Biology, VU University Amsterdam, De Boelelaan 1108, 1081, HZ, Amsterdam, The Netherlands. ${ }^{3}$ Yoba for Life Foundation, 
Hunzestraat 133-A, 1079, WB, Amsterdam, The Netherlands. ${ }^{4}$ Department of Nursing, Muni University, P.O. Box 725, Arua, Uganda.

\section{Received: 15 January 2019 Accepted: 7 March 2019 Published online: 15 March 2019}

\section{References}

Abdel-Hadi A, Schmidt-Heydt M, Parra R, Geisen R, Magan N. A systems approach to model the relationship between aflatoxin gene cluster expression, environmental factors, growth and toxin production by Aspergillus flavus. J Royal Soc Interface. 2012;9(69):757-67.

Aka S, Camara F, Nanga YZ, Loukou YG, Dje KM. Evaluation of organic acids and sugars contents during the production of 'Tchapalo', a traditional sorghum beer in Côte d'Ivoire. J Food Technol. 2008;6(5): 189-95.

Aka S, Konan G, Fokou G, Dje KM, Bonfoh B. Review on African traditional cereal beverages. Am J Res Commun. 2014;2(5):103-53.

Alborch L, Bragulat M, Castellá G, Abarca M, Cabañes F. Mycobiota and mycotoxin contamination of maize flours and popcorn kernels for human consumption commercialized in Spain. Food Microbiol. 2012;32(1):97-103.

Bationo JF, Nikiéma PA, Koudougou K, Ouédraogo M, Bazié SR, Sanou E, Barro N. Assessment of aflatoxin B1 and ochratoxin a levels in sorghum malts and beer in Ouagadougou. Afr J Food Sci. 2015;9(7):417-20.

Berghofer LK, Hocking AD, Miskelly D, Jansson E. Microbiology of wheat and flour milling in Australia. Int J Food Microbiol. 2003;85(1-2):137-49.

Black RE, Victora CG, Walker SP, Bhutta ZA, Christian P, De Onis M, Ezzati M, Grantham-Mc-Gregor S, Katz J, Martorell R. Maternal and child undernutrition and overweight in low-income and middle-income countries. Lancet. 2013; 382(9890):427-51.

Chelule P, Mbongwa H, Carries S, Gqaleni N. Lactic acid fermentation improves the quality of amahewu, a traditional south African maize-based porridge. Food Chem. 2010;122(3):656-61.

EAC, East African Community. (2011). Sorghum flour - specification (DEAS 95: 2016). https://members.wto.org/crnattachments/2016/TBT/UGA/16_3723_00_ e.pdf. Accessed 2 Jan 2018.

EAC East African Community (2016) Millet flour - specification (EAS 89: 2011). https://law.resource.org/pub/eac/ibr/eas.89.2011.pdf. Accessed 2 Jan 2018.

El-Nezami H, Kankaanpaa P, Salminen S, Ahokas J. Ability of dairy strains of lactic acid bacteria to bind a common food carcinogen, aflatoxin B1. Food Chem Toxicol. 1998;36(4):321-6.

El-Nezami H, Mykkänen H, Kankaanpää P, Salminen S, Ahokas J. Ability of lactobacillus and Propionibacterium strains to remove aflatoxin B1 from the chicken duodenum. J Food Prot. 2000;63(4):549-52.

EU European Union (2006) Commission regulation (EC) no 1881/2006 of 19 December 2006. Setting maximum levels for certain contaminants in foodstuffs. https://eur-lex.europa.eu/legal-content/EN/TXT/PDF/?uri=CELEX: 02006R1881-20170728\&rid=1. Accessed 19 Sept 2018

Ezekiel CN, Abia WA, Ogara IM, Sulyok M, Warth B, Krska R. Fate of mycotoxins in two popular traditional cereal-based beverages (kunu-zaki and pito) from rural Nigeria. LWT Food Sci Technol. 2015:60(1):137-41.

Ezekiel CN, Ayeni Kl, Misihairabgwi JM, Somorin YM, Chibuzor-Onyema IE, Oyedele OA, Abia WA, Sulyok M, Shephard GS, Krska R. Traditionally processed beverages in Africa: a review of the mycotoxin occurrence patterns and exposure assessment. Compr Rev Food Sci Food Saf. 2018;17(2): 334-51.

Garrido C, Pezzani CH, Pacin A. Mycotoxins occurrence in Argentina's maize (Zea mays L.), from 1999 to 2010. Food Control. 2012;25(2):660-5.

Gratz S, Mykkänen H, Ouwehand A, Juvonen R, Salminen S, El-Nezami H. Intestinal mucus alters the ability of probiotic bacteria to bind aflatoxin B1 in vitro. Appl Environ Microbiol. 2004;70(10):6306-8.

Gratz S, Täubel M, Juvonen R, Viluksela M, Turner P, Mykkänen H, El-Nezami H. Lactobacillus rhamnosus strain GG modulates intestinal absorption, fecal excretion, and toxicity of aflatoxin B1 in rats. Appl Environ Microbiol. 2006; 72(11):7398-400.

Hamidi A, Mirnejad R, Yahaghi E, Behnod V, Mirhosseini A, Amani S, Sattari S, Darian EK. The aflatoxin B1 isolating potential of two lactic acid bacteria. Asian Pac J Trop Biomed. 2013;3(9):732-6.

Haskard CA, El-Nezami HS, Kankaanpää PE, Salminen S, Ahokas JT. Surface binding of aflatoxin B1 by lactic acid bacteria. Appl Environ Microbiol. 2001; 67(7):3086-91.
Hell K, Cardwell K, Setamou M, Poehling H-M. The influence of storage practices on aflatoxin contamination in maize in four agroecological zones of Benin, West Africa. J Stored Prod Res. 2000;36(4):365-82.

Hernandez-Mendoza A, Guzman-de-Peña D, Garcia H. Key role of teichoic acids on aflatoxin B1 binding by probiotic bacteria. J Appl Microbiol. 2009;107(2): 395-403.

Huang L, Duan C, Zhao Y, Gao L, Niu C, Xu J, Li S. Reduction of aflatoxin B1 toxicity by Lactobacillus plantarum C88: a potential probiotic strain isolated from Chinese traditional fermented food "tofu". PLoS One. 2017;12(1):1-16. https://doi.org/10.1371/journal.pone.0170109.

Hussaini AM, Timothy AG, Olufunmilayo HA, Ezekiel AS, Godwin HO. Fungi and some mycotoxins found in mouldy sorghum in Niger state, Nigeria. World J Agric Sci. 2009;5(1):5-17.

Huwig A, Freimund S, Käppeli O, Dutler H. Mycotoxin detoxication of animal feed by different adsorbents. Toxicol Lett. 2001;122(2):179-88.

lyanda A, Anetor J, Oparinde D, Adeniyi F. Aflatoxin contamination of foodstuffs: its health implications in sub-Saharan Africa. Ann Exp Biol. 2014;2(3):63-73.

Jalili M. A review on aflatoxins reduction in food. Iran J Health Saf Environ. 2016; 3(1):445-59.

Jay MJ. Modern food microbiology. New York: Van Nostrand Reinhold; 1992.

Kamala A, Shirima C, Jani B, Bakari M, Sillo H, Rusibamayila N, De Saeger S, Kimanya M, Gong YY, Simba A. Outbreak of an acute aflatoxicosis in Tanzania during 2016. World Mycotoxin J. 2018;11(3):311-20.

Kankaanpää P, Tuomola E, El-Nezami H, Ahokas J, Salminen SJ. Binding of aflatoxin $\mathrm{B} 1$ alters the adhesion properties of Lactobacillus rhamnosus strain GG in a Caco-2 model. J Food Prot. 2000;63(3):412-4.

Karlovsky P, Suman M, Berthiller F, De Meester J, Eisenbrand G, Perrin I, Oswald IP, Speijers G, Chiodini A, Recker T. Impact of food processing and detoxification treatments on mycotoxin contamination. Mycotoxin Res. 2016;32(4):179-205.

Kateu KK. A study of traditional production of Ugandan fermented cereal beverage, Obushera: Dissertation, Western Sydney University; 1998.

Kihara RW. Levels of aflatoxins in flour ingredients from micro, small and medium enterprises in Nairobi county and the effect on feeding rats: Dissertation, University of Nairobi; 2015.

Klich MA. Environmental and developmental factors influencing aflatoxin production by Aspergillus flavus and Aspergillus parasiticus. Mycosci. 2007;48(2):71-80.

Kumar P, Mahato DK, Kamle M, Mohanta TK, Kang SG. Aflatoxins: a global concern for food safety, human health and their management. Front Microbiol. 2017;7:2170.

Lee HJ, Ryu D. Worldwide occurrence of mycotoxins in cereals and cerealderived food products: public health perspectives of their co-occurrence. J Agri Food Chem. 2017;65(33):7034-51.

Liew W-P-P, Nurul-Adilah Z, Than LTL, Mohd-Redzwan S. The binding efficiency and interaction of Lactobacillus casei Shirota toward aflatoxin B1. Front Microbiol. 2018;9:1-12. https://doi.org/10.3389/fmicb.2018.01503.

Mably M, Mankotia M, Cavlovic P, Tam J, Wong L, Pantazopoulos P, Calway P, Scott PM. Survey of aflatoxins in beer sold in Canada. Food Addit Contam. 2005:22(12):1252-7.

Makun HA, Ojochenemi AD, Yemi AHR, Tahir N, Okechukwu OJ, Saidu MA, Ayobami OB. Determination of aflatoxins in sesame, Rice, millet and Acha from Nigeria using HPLC. Chem Sci Trans. 2014;3(4):1516-24.

Mannaa M, Kim KD. Influence of temperature and water activity on deleterious fungi and mycotoxin production during grain storage. Mycobiol. 2017;45(4): 240-54.

Mashak Z, Sodagari H, Mashak B, Niknafs S. Chemical and microbial properties of two Iranian traditional fermented cereal-dairy based foods: Kashk-e Zard and Tarkhineh. Int J Biosci. 2014;4(12):124-33.

Matumba L, Monjerezi M, Khonga EB, Lakudzala DD. Aflatoxins in sorghum, sorghum malt and traditional opaque beer in southern Malawi. Food Control. 2011;22(2):266-8.

Matumba L, Van Poucke C, Biswick T, Monjerezi M, Mwatseteza J, De Saeger S. A limited survey of mycotoxins in traditional maize based opaque beers in Malawi. Food Control. 2014:36(1):253-6.

Mokoena MP, Chelule PK, Gqaleni N. Reduction of fumonisin B1 and zearalenone by lactic acid bacteria in fermented maize meal. J Food Prot. 2005;68(10): 2095-9.

Mousa W, Ghazali FM, Jinap S, Ghazali HM, Radu S. Modeling growth rate and assessing aflatoxins production by Aspergillus flavus as a function of water activity and temperature on polished and brown rice. J Food Sci. 2013;78(1): M56-63. 
Mukisa IM, Ntaate D, Byakika S. Application of starter cultures in the production of Enturire-a traditional sorghum-based alcoholic beverage. Food Sci Nutr. 2017;5(3):609-16.

Mukisa IM, Porcellato D, Byaruhanga YB, Muyanja C, Rudi K, Langsrud T, Narvhus $J A$. The dominant microbial community associated with fermentation of Obushera (sorghum and millet beverages) determined by culture-dependent and culture-independent methods. Int J Food Microbiol. 2012;160(1):1-10.

Nakajima M, Tsubouchi $\mathrm{H}$, Miyabe M. A survey of ochratoxin a and aflatoxins in domestic and imported beers in Japan by immunoaffinity and liquid chromatography. J-AOAC Int. 1999;82:897-902.

N'Guessan Y, Bedikou M, Zoue L, Goualie B, Niamke S. Physicochemical, nutritive and safety evaluation of local cereal flours sold in areas of the district of Abidjan-Côte d'Ivoire. J Appl Biosci. 2014;83(1):7579-94.

Nigussie A, Bekele T, Gemede HF, Woldegiorgis AZ. Level of aflatoxins in industrially brewed local and imported beers collected from Ethiopia market. Cogent Food Agri. 2018;4(1):1453317.

Nkwe DO, Taylor JE, Siame BA. Fungi, aflatoxins, fumonisin B I and zearalenone contaminating sorghum-based traditional malt, wort and beer in Botswana. Mycopathologia. 2005;160(2):177-86.

Ntuli V, Mekbib SB, Asita A, Molebatsi N, Makotoko M, Chatanga P. Microbial and physicochemical characterization of maize and wheat flour from a milling company, Lesotho. Internet J Food Saf. 2013;15:11-9.

Nyamete FA, Bennink M, Mugula J. Potential of lactic acid fermentation in reducing aflatoxin B1 in Tanzania maize-based gruel. Afr J Food Agric Nutr Dev. 2016;16(3):11139-51.

Obonyo MA, Salano EN. Perennial and seasonal contamination of maize by aflatoxins in eastern Kenya. Int J Food Contam. 2018;5(1):6.

Odhav B, Naicker V. Mycotoxins in south African traditionally brewed beers. Food Addit Contam. 2002;19(1):55-61.

Odoemelam S, Osu C. Aflatoxin B1contamination of some edible grains marketed in Niger. J Chem. 2009;6(2):308-14

Okaru AO, Abuga KO, Kibwage IO, Hausler T, Luy B, Kuballa T, Rehm J, Lachenmeier DW. Aflatoxin contamination in unrecorded beers from Kenyaa health risk beyond ethanol. Food Control. 2017;79:344-8.

Okeke CA, Ezekiel CN, Nwangburuka CC, Sulyok M, Ezeamagu CO, Adeleke RA, Dike SK, Krska R. Bacterial diversity and mycotoxin reduction during maize fermentation (steeping) for Ogi production. Front Microbiol. 2015;6:1402.

Osamwonyi $U$, Wakil S. Isolation of fungal species from fermentating pearl millet gruel and determination of their antagonistic activities against indicator bacterial species. Niger Food J. 2012;30(1):35-42.

Peltonen K, El-Nezami H, Haskard C, Ahokas J, Salminen S. Aflatoxin B1 binding by dairy strains of lactic acid bacteria and bifidobacteria. J Dairy Sci. 2001; 84(10):2152-6.

Peters J, van Dam R, van Doorn R, Katerere D, Berthiller F, Haasnoot W, Nielen MW. Mycotoxin profiling of 1000 beer samples with a special focus on craft beer. PLoS One. 2017;12(10):e0185887.

Plavšić DV, Škrinjar MM, Psodorov ĐB, Šarić LĆ, Psodorov DD, Varga AO, Mandić Al. Mycopopulations of grain and flour of wheat, corn and buckwheat. Food Feed Res. 2017:44(1):39-45.

Probst C, Njapau H, Cotty PJ. Outbreak of an acute aflatoxicosis in Kenya in 2004: identification of the causal agent. Appl Environ Microbiol. 2007;73(8):2762-4.

Reddy BN, Raghavender CR. Outbreaks of aflatoxicoses in India. Afr J Food Agri Nutr Dev. 2007;7(5).

Romani L. Immunity to fungal infections. Nat Rev Immunol. 2004;4(1):11.

Scott PM, Lawrence GA. Determination of aflatoxins in beer. J AOAC Int. 1997; 80(6):1229-34.

Shetty PH, Jespersen L. Saccharomyces cerevisiae and lactic acid bacteria as potential mycotoxin decontaminating agents. Trends Food Sci Technol. 2006; 17(2):48-55.

Sirma A, Senerwa D, Grace D, Makita K, Mtimet N, Kang'ethe E, Lindahl J. Aflatoxin B1 occurrence in millet, sorghum and maize from four agroecological zones in Kenya. Afr J Food Agric Nutr Dev. 2016;16(3):10991-1003.

Taheur FB, Fedhila K, Chaieb K, Kouidhi B, Bakhrouf A, Abrunhosa L. Adsorption of aflatoxin B1, zearalenone and ochratoxin a by microorganisms isolated from kefir grains. Int J Food Microbiol. 2017;251:1-7.

Udovicki B, Audenaert K, De Saeger S, Rajkovic A. Overview on the mycotoxin incidence in Serbia in the period 2004-2016. Toxins. 2018a;10(7):279.

Udovicki B, Djekic I, Stankovic S, Obradovic A, Rajkovic A. Impact of climatic conditions on fumonisins in maize grown in Serbia. World Mycotoxin J. 2018b:1-8.
UNBS Uganda National Bureau of Standards (2009) Fermented (non-alcoholic) cereal beverages - specification (DUS 872:2009). https://members.wto.org/ crnattachments/2018/SPS/UGA/18_5341_00_e.pdf. Accessed 23 July 2017.

Utami R, Utami T, Suparmo S, Rahayu ES. Binding of aflatoxin B1 to Lactobacillus paracasei SNP-2 and stability of bacteria-AFB1 complex. Indonesian Food Nutr Progress. 2017;14(1):1-8.

Verheecke C, Liboz T, Mathieu F. Microbial degradation of aflatoxin B1: current status and future advances. Int J Food Microbiol. 2016;237:1-9.

Wacoo AP, Mukisa IM, Meeme R, Byakika S, Wendiro D, Sybesma W, Kort R. Probiotic enrichment and reduction of aflatoxins in a traditional African maize-based fermented food. Nutrients. 2019;11(2):265.

Warth B, Parich A, Atehnkeng J, Bandyopadhyay R, Schuhmacher R, Sulyok M, Krska R. Quantitation of mycotoxins in food and feed from Burkina Faso and Mozambique using a modern LC-MS/MS multitoxin method. J Agric Food Chem. 2012:60(36):9352-63.

Weledesemayat G, Gezmu T, Woldegiorgis A, Gemede H. Study on Aspergillus species and aflatoxin levels in sorghum (Sorghum bicolor L.) stored for different period and storage system in Kewet districts, northern Shewa, Ethiopia. J Food Sci Nutr. 2016;2:010.

Westby A, Reilly A, Bainbridge Z. Fermentation on naturally occurring toxins. Food Control. 1997:8(5/6):329.
Ready to submit your research? Choose BMC and benefit from:

- fast, convenient online submission

- thorough peer review by experienced researchers in your field

- rapid publication on acceptance

- support for research data, including large and complex data types

- gold Open Access which fosters wider collaboration and increased citations

- maximum visibility for your research: over $100 \mathrm{M}$ website views per year

At $\mathrm{BMC}$, research is always in progress.

Learn more biomedcentral.com/submissions 